\title{
Frequency Versus Quantity: Phenotypic Response of Two Wheat Varieties to Water and Nitrogen Variability
}

\author{
Olivia H. Cousins ${ }^{1,2,3}$ (D) - Trevor P. Garnett ${ }^{1,4} \cdot$ Amanda Rasmussen $^{2} \cdot$ Sacha J. Mooney $^{2} \cdot$ Ronald J. Smernik ${ }^{1}$. \\ Chris J. Brien ${ }^{1,4} \cdot$ Timothy R. Cavagnaro ${ }^{1}$
}

Received: 16 September 2020 / Accepted: 23 March 2021 / Published online: 20 April 2021

(C) The Author(s) 2021

\begin{abstract}
Due to climate change, water availability will become increasingly variable, affecting nitrogen $(\mathrm{N})$ availability. Therefore, we hypothesised watering frequency would have a greater impact on plant growth than quantity, affecting $\mathrm{N}$ availability, uptake and carbon allocation. We used a gravimetric platform, which measures the unit of volume per unit of time, to control soil moisture and precisely compare the impact of quantity and frequency of water under variable $\mathrm{N}$ levels. Two wheat genotypes (Kukri and Gladius) were used in a factorial glasshouse pot experiment, each with three $\mathrm{N}$ application rates $\left(25,75\right.$ and $150 \mathrm{mg} \mathrm{N} \mathrm{kg}^{-1}$ soil) and five soil moisture regimes (changing water frequency or quantity). Previously documented drought tolerance, but high $\mathrm{N}$ use efficiency, of Gladius as compared to Kukri provides for potentially different responses to $\mathrm{N}$ and soil moisture content. Water use, biomass and soil $\mathrm{N}$ were measured. Both cultivars showed potential to adapt to variable watering, producing higher specific root lengths under low $\mathrm{N}$ coupled with reduced water and reduced watering frequency ( $48 \mathrm{~h}$ watering intervals), or wet/dry cycling. This affected mineral $\mathrm{N}$ uptake, with less soil $\mathrm{N}$ remaining under constant watering $\times$ high moisture, or $48 \mathrm{~h}$ watering intervals $\times$ high moisture. Soil $\mathrm{N}$ availability affected carbon allocation, demonstrated by both cultivars producing longer, deeper roots under low N. Reduced watering frequency decreased biomass more than reduced quantity for both cultivars. Less frequent watering had a more negative effect on plant growth compared to decreasing the quantity of water. Water variability resulted in differences in $\mathrm{C}$ allocation, with changes to root thickness even when root biomass remained the same across $\mathrm{N}$ treatments. The preferences identified in wheat for water consistency highlights an undeveloped opportunity for identifying root and shoot traits that may improve plant adaptability to moderate to extreme resource limitation, whilst potentially encouraging less water and nitrogen use.
\end{abstract}

Keywords Biomass allocation · Nitrogen use efficiency · Plant physiology · Triticum aestivum · Variable water · Water use efficiency

Olivia H. Cousins

olivia.co@hotmail.co.uk

1 The Waite Research Institute and The School of Agriculture, Food and Wine, University of Adelaide-Waite Campus, PMB1, Glen Osmond, SA 5064, Australia

2 School of Biosciences, University of Nottingham, Sutton Bonington LE12 5RD, UK

3 Agriculture and Environment Department, Harper Adams University, Newport TF10 8NB, UK

4 The Plant Accelerator, University of Adelaide-Waite Campus, PMB1, Glen Osmond, SA 5064, Australia

\section{Introduction}

Current climate projections indicate increased variability in precipitation in many regions of the world (Rebetzke et al. 2009). This is likely to have a profound impact on plants grown in rain-fed systems. Similarly, in irrigated systems as rainfall frequency becomes more variable, there will be increased competition for water resources. Taken together, these projected changes are likely to have an important impact on global food production systems. Improving our understanding of crop responses to limited and/or variable rainfall and irrigation is a key priority for future efforts concerned with the sustainable intensification of agriculture.

Plant growth is affected by the amount, seasonality and frequency of water supply (Austin et al. 2004; Gibson-Forty et al. 2016; Izanloo et al. 2008). It is well established that a 
reduction in rainfall significantly reduces grassland biomass compared to reduced rainfall frequency (Gibson-Forty et al. 2016). This is well demonstrated by Gibson-Forty et al. (2016), where a reduced magnitude (50\% reduction in water amount) decreased total biomass, photosynthesis and stomatal conductance, compared to reduced frequency ( 8 days between watering events). In contrast, Padilla et al. (2013) found specific root length and total root length was higher when grassland species received the same amount of water once a week (pulsed) as opposed to thrice weekly (regular). A thrice weekly watering pattern is very common in pot trials; therefore, the implications of watering frequency is important. There was substantial water stress at the end of the pulsed watering cycle; however, it did improve water use efficiency, most likely due to the increased soil moisture as a result of re-watering, which, in turn, encouraged further root growth as plants search for water and/or nutrients. It has been shown that a soil water deficit can encourage roots to grow longer and deeper (Ješko et al. 1997). Early water deficit has shown an increase in root biomass in relation to shoot biomass, with plants able to recover upon rewatering; however, an imposed water deficit mid-season can cause severe damage to both below- and aboveground biomass, even with subsequent rewatering (Asseng et al. 1998). These differences in plant trait responses highlight the importance and complexity of plant phenotypic plasticity (the physiological or phenotypic changes in a plant). Taken together, changes in the amount and frequency of supply can have both direct and indirect impacts on plants.

Water availability affects not only plant growth but the concentration of plant available nutrients too. However, studies have shown that crops can perform better with colimitation of resources (where both water and $\mathrm{N}$ are limited). For example, Cousins et al. (2020) found reduced water coupled with medium soil $\mathrm{N}$ concentration encouraged plant growth, particularly increasing root growth. In other work, grain yield, $\mathrm{N}$ use efficiency and water use efficiency increased with an increase in water and $\mathrm{N}$ co-limitation (Cossani et al. 2010). This concept of resource allocation was suggested by Bloom et al. (1985), whereby plants adjust their carbon allocation particularly between shoot and roots until the sugar produced equals the cost of sugar production. Lower soil $\mathrm{N}$ availability has been shown to encourage more root biomass in wheat (López-Bucio et al. 2003). In contrast, too much soil $\mathrm{N}$ can be detrimental to growth, resulting in a decrease in root length in wheat (Comfort et al. 1988). The amount, form and behaviour of soil $\mathrm{N}$ are strongly affected by soil water supply (Burger et al. 2005). Under drought conditions, available $\mathrm{N}$ in soil is reduced partly due to a decrease in microbial activity, which slows $\mathrm{N}$ mineralisation (Jensen et al. 2003). High rainfall or irrigation (water pulses) could encourage breakdown of $\mathrm{N}$ forms locked up in organic matter, thus increasing $\mathrm{N}$ availability (López-Bellido et al. 2005; Schwinning and Sala 2004; Wang et al. 2015). These water pulses increase drainage water and thus increase the risk of Nfertiliser leaching and surface run-off into bodies of water Bijay-Singh et al. 1995; Carstensen et al. 2014), reducing plant growth, plant $\mathrm{N}$ content, particularly post-anthesis accumulation and remobilisation of $\mathrm{N}$, which in turn result in reduce grain yield (Masoni et al. 2008). Thus, this predicament often results in more fertiliser being applied to compensate for low $\mathrm{N}$ availability. Increased leaching could also reduce plant growth Therefore, it is necessary to understand how $\mathrm{N}$ behaves under different water conditions (mirroring erratic rainfall patterns), and how we can maximise $\mathrm{N}$ use efficiency under such water conditions. Moreover, a more targeted approach to crop management is needed, where the plant response to water and $\mathrm{N}$ can be measured, and subsequently, irrigation and fertiliser applications optimised.

Since weather events are becoming more extreme, both plasticity and genotypic diversity in crops are becoming increasingly important. Many plant varieties differ in their responses to water and nutrients, particularly adapting their roots to optimise growth (Hurd 1964; Lynch 1995; Ober et al. 2014). Root biomass allocation is central to optimising water and $\mathrm{N}$ use efficiencies. Under any one condition, a root system that allows foraging for nutrients or water, but not at the expense of crop yield, is ideal (Elazab et al. 2016). These root foraging strategies can differ depending on soil depth and water or nutrient hotspots. Due to the complexity of root plasticity in response to environmental conditions, identification of the different root traits beneficial to plant growth are still in progress. This means there is a clear need for detailed understanding of plant responses to variable water and $\mathrm{N}$ resource supply if we are to identify target traits in plant breeding programmes; such efforts will require fine-scale information on plant response to variable water supply.

Understanding how water and $\mathrm{N}$ create variability in plant plasticity is an important but complex undertaking. As noted above, some studies have watered plants at different frequencies to establish pulsed and regular watering treatments; however, such approaches still have a degree of pulsing (e.g. watering thrice weekly as opposed to weekly). There is a need for studies with a high degree of control over water supply; however, precisely controlling and monitoring soil water conditions in real time presents considerable technical difficulties. It is possible to use wicking beds or tension tables, where pots are placed onto a bed of sand equilibrated to a precise matric potential allowing plants to take up water according to use (Araya et al. 2010; Semananda et al. 2016; Tinklin and Weatherley 1968). However, such an approach does not lend itself well to establishing cyclic watering patterns that persist in the field. One way to overcome this problem is to use automated gravimetric platforms that allow very fine-scale control of soil moisture dynamics by weighing each individual plant pot and measuring water added (Rahimi Eichi et al. 2019; Riley et al. 2019; Tran et al. 2020). These fine scale 
weight measurements allow monitoring of plant adaptability by measuring the amount of water used over time due to environmental change, i.e. water or $\mathrm{N}$ treatments (Cousins et al. 2020). The ability of a gravimetric system to simulate possible rainfall or irrigation outcomes in the field make it a unique tool to answer questions related to precision agriculture. Importantly, gravimetric systems record water use on a very fine temporal scale, providing valuable insights into plant water use over their entire growth cycle.

Here, we present results of an investigation into the combined effects of (precisely controlled) variable water and $\mathrm{N}$ supply on two cultivars of wheat (Gladius and Kukri). We hypothesised (1) that the frequency of watering would have a greater impact on plant growth than quantity, and (2) the water regimes imposed would affect $\mathrm{N}$ availability, uptake and subsequently create differences in carbon allocation. Based on the different water and $\mathrm{N}$ use efficiencies of both wheat cultivars, we also hypothesised that (3) Gladius and Kukri would showcase different phenotypes, although any differences would need to be statistically confirmed in a combined experiment for both varieties.

\section{Materials and Methods Introduction}

\subsection{Glasshouse Plant Experiment Set-up}

The growth medium used for this experiment was a mixture of clay loam, UC (University of California; Baker 1957) sand mix and cocopeat (1:1:1 W:W:W) (referred to as 'soil' henceforth). This medium has been used extensively in previous experiments on $\mathrm{N}$ and water responses of wheat (e.g. Cousins et al. 2020; Honsdorf et al. 2014; Takahashi et al. 2015). A $660 \mathrm{~kg}$ batch of the soil was prepared by combining clay loam, UC sand mix and cocopeat (220 kg each) with $60 \mathrm{~L}$ of a solution containing basal nutrients at the following concentrations: dolomite lime $0.98 \mathrm{~g} \mathrm{~L}^{-1}$, ag lime $2.72 \mathrm{~g} \mathrm{~L}^{-1}$, hydrated lime $0.63 \mathrm{~g} \mathrm{~L}^{-1}$, gypsum $0.98 \mathrm{~g} \mathrm{~L}^{-1}$, superphosphate $1.96 \mathrm{~g} \mathrm{~L}^{-1}$, iron sulphate $2.45 \mathrm{~g} \mathrm{~L}^{-1}$, iron chelate $0.163 \mathrm{~g} \mathrm{~L}^{-1}$, micromax (ICL Australia and New Zealand, New South Wales, Australia) $0.98 \mathrm{~g} \mathrm{~L}^{-1}$. This ensured $\mathrm{N}$ was the only limiting nutrient. Additional water was added to assist mixing, such that the final gravimetric water content of the soil was $0.18 \mathrm{~g} \mathrm{~g}^{-1}$. The field capacity of the soil (FC hereafter) was determined to be $16 \%$ (i.e. a gravimetric water content of $0.16 \mathrm{~g} \mathrm{~g}^{-1}$ ) using the method described by Cavagnaro (2016). In brief, a known sample of soil was packed into a sintered glass funnel connected to a $100 \mathrm{~cm}$ water column. The soil was saturated with water and allowed to drain for $48 \mathrm{~h}$. The soil was weighed, then dried for $48 \mathrm{~h}$ at $105^{\circ} \mathrm{C}$, and weighed again.

The soil batch was split into three portions, to which urea was added with thorough mixing at three different rates:
$25 \mathrm{mg}$ of $\mathrm{N} \mathrm{kg}^{-1}$ (equivalent to $33 \mathrm{~kg} \mathrm{ha}^{-1}$ ) of soil (referred to as $25 \mathrm{~N}$ hereafter); $75 \mathrm{mg}$ of $\mathrm{N} \mathrm{kg}^{-1}\left(100 \mathrm{~kg} \mathrm{ha}^{-1}\right)$ of soil (75 N hereafter) and $150 \mathrm{mg}$ of $\mathrm{N} \mathrm{kg}^{-1}\left(200 \mathrm{~kg} \mathrm{ha}^{-1}\right)$ of soil ( $150 \mathrm{~N}$ hereafter). After the addition of the urea to the soil, the concentrations of ammonium $\left(\mathrm{NH}_{4}{ }^{+} \mathrm{N}\right)$ and nitrate $\left(\mathrm{NO}_{3}{ }^{-} \mathrm{-}\right)$ in the soils were measured on $2 \mathrm{M} \mathrm{KCl}$ extracts, as described by Forster (1995) and Miranda et al. (2001). The starting soils of $25,75,150 \mathrm{mg}$ of $\mathrm{N} \mathrm{kg}^{-1}$ of soil had $22 \pm 1.0 ; 69 \pm 0.1 ; 90$ \pm 1.1 of $\mathrm{NH}_{4}{ }^{+}-\mathrm{N}$ (mg kg${ }^{-1}$ dry soil); and $10 \pm 0.9 ; 11 \pm 0.2 ; 10$ \pm 1.5 of $\mathrm{NO}_{3}^{-}-\mathrm{N}$ (mg kg${ }^{-1}$ dry soil), respectively (see Online Resource Table S1). Concentrations of $\mathrm{NH}_{4}{ }^{+}-\mathrm{N}$ increased with increasing urea, whereas $\mathrm{NO}_{3}{ }^{-} \mathrm{N}$ remained at similar levels.

For each treatment, $2.2 \mathrm{~kg}$ of air-dried soil equivalent was placed in a 2.5 -L free-draining pot $(145 \times 190 \mathrm{~mm}$, diameter $\times$ height); in total, there were 120 pots with wheat and 21 plantfree controls (to compare water use with the plants). Since the initial water content of the soil $\left(0.18 \mathrm{~g} \mathrm{~g}^{-1}\right)$ was higher than the initial target moisture content $\left(0.16 \mathrm{~g} \mathrm{~g}^{-1}\right.$, i.e. FC), all pots were placed in the glasshouse and dried down until they reached FC then held at this water content until water regimes were implemented between 12 and 14 days.

On 20 June 2017, seeds (two per pot) were sown directly into pots; half of the pots were sown with Triticum aestivum cv. Gladius, and others with cv. Kukri (both spring wheat varieties). Kukri is derived from CIMMYT wheat lines and was adapted at the University of Adelaide Roseworthy breeding programme for 1999 release by Seednet. Gladius is derived from a complex cross and was selected by breeders for grain yield maintenance under drought stress, and then publicly released in 2007 (Kastury et al. 2018; Melino et al. 2015). Gladius was documented as high yielding under drought conditions (Bennett et al. 2012; Izanloo et al. 2008), and both Gladius and Kukri have previously demonstrated high N use efficiency (Mahjourimajd et al. 2016; Sitlington Hansen 2019). Therefore, growing these cultivars together could provide potentially different responses to $\mathrm{N}$ and soil moisture content. After seedling emergence ( 5 days after sowing), seedlings were thinned to one per pot, and the soil surface was covered with a semi-permeable mesh to allow water to filter through but minimise evaporative loss.

This experiment utilised an automated gravimetric watering system (DroughtSpotter, Phenospex, Heerlen, Netherlands). Briefly, this system weighs each plant separately using the load cell every $10 \mathrm{~min}$, then water is added to each pot when it falls below a certain target weight. The system collects all the individual pot weights over time, in addition to the amount of water added over time (Fig. 1). This system allowed for constant monitoring of water addition over the whole experiment. Conditions in the glasshouse were 22/ $15{ }^{\circ} \mathrm{C}$ day/night, and light levels were supplemented with $400 \mu \mathrm{mol} / \mathrm{m}^{2} / \mathrm{s}$ LEDs (GreenPower LED toplighting module DR/B HB 400 V, Philips Electronics Australia Ltd., New 

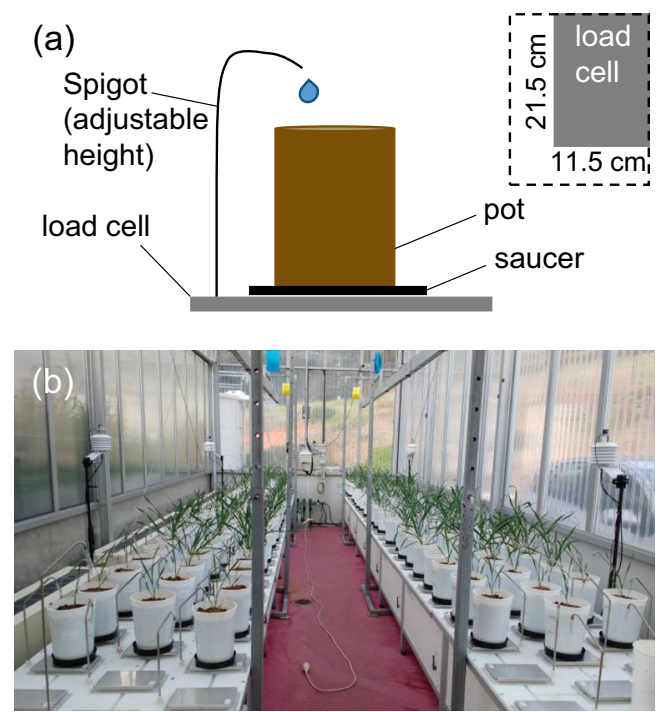

Fig. 1 Diagram of gravimetric watering system, with watering done from the top of the pot

South Wales, Australia) with a 12/12 h day/night photoperiod. The relative humidity $(\mathrm{RH})$ of the glasshouse averaged between 48 and $68 \% \mathrm{RH}$.

Five water treatments were implemented (Table 1). Two treatments involved watering to field capacity: one (FC) was watered to weight as required (monitored every $10 \mathrm{~min}$ ) and one (FC $48 \mathrm{~h}$ ) was watered only every $48 \mathrm{~h}$. A further two were kept at half field capacity: one $(0.5 \mathrm{FC})$ was watered to weight as required (monitored every $10 \mathrm{~min})$ and one $(0.5 \mathrm{FC}$ $48 \mathrm{~h}$ ) was watered only every $48 \mathrm{~h}$. The final treatment was a wet/dry treatment where pots were dried down to half of field capacity, then re-wet to field capacity and maintained at field capacity until harvest (Fig. 2). With the gravimetric system, every time the pot weighed $0.5 \%$ below the target weight for a particular soil moisture content ( $16 \%$ for $\mathrm{FC}, 8 \%$ for $0.5 \mathrm{FC}$ ), it was watered back to that soil moisture content. With the $48 \mathrm{~h}$ watering treatments, pots were watered to the target soil moisture content, but the soil moisture content was allowed to drop approximately $3 \%$ in between the 48 -h irrigation. The automated gravimetric watering system was programmed to rewater up to the target weight. (Table 1). As expected, there was no water drainage from the pots in any of the treatments since water contents were maintained below saturation at all times.

\subsection{Plant Sampling and Analysis}

After 41 days of growth (31 July 2017), plants were destructively harvested by carefully removing soil from the pots (a sub-sample of soil was retained for $\mathrm{N}$ analysis, see below), and roots washed of any adhering soil using reverse osmosis (RO) water. The roots were partially pot-bound. The roots and aboveground biomass were separated, and fresh weights determined. Total root length was measured (on a sub-sample of roots of a known fresh weight) using the gridline intersection method (Newman 1966). The plants varied between 37 and 58 on the Zadoks growth scale, with the flag leaf just visible on the least developed plants (Zadoks stage 37) and up to $80 \%$ of the wheat spike visible in the most developed plants (late heading, Zadoks stage 58).

All plant biomass was oven-dried $\left(60^{\circ} \mathrm{C}\right)$ until a constant weight was achieved and dry weights recorded and root:shoot ratios calculated. The dried shoot material was homogenised and ground to a fine powder, using a ring mill (Standard Ring Mill, SRM-RC-3P; Rocklabs Ltd., Auckland, New Zealand)

Table 1 Combinations of water quantity, frequency and $\mathrm{N}$ amounts

\begin{tabular}{|c|c|c|}
\hline Water quantity & Water frequency & Nitrogen \\
\hline $\begin{array}{l}\text { FC (field capacity) } \\
16 \% \text { gravimetric moisture }\end{array}$ & Constant & $\begin{array}{l}\left.25 \mathrm{~N} \text { (25 mg N kg }{ }^{-1} \text { soil }\right) \\
75 \mathrm{~N}\left(75 \mathrm{mg} \mathrm{N} \mathrm{kg}^{-1} \text { soil }\right) \\
150 \mathrm{~N}\left(150 \mathrm{mg} \mathrm{N} \mathrm{kg}^{-1} \text { soil }\right)\end{array}$ \\
\hline $\begin{array}{l}\text { FC } 48 \mathrm{~h} \\
\text { Watered every } 48 \mathrm{~h} \text { from } 13 \text { to } 16 \%\end{array}$ & 48-h intervals & $\begin{array}{l}25 \mathrm{~N}\left(25 \mathrm{mg} \mathrm{N} \mathrm{kg}^{-1} \text { soil }\right) \\
75 \mathrm{~N}\left(75 \mathrm{mg} \mathrm{N} \mathrm{kg}^{-1} \text { soil }\right) \\
150 \mathrm{~N}\left(150 \mathrm{mg} \mathrm{N} \mathrm{kg}^{-1} \text { soil }\right)\end{array}$ \\
\hline $\begin{array}{l}0.5 \mathrm{FC} \\
8 \% \text { gravimetric moisture }\end{array}$ & 48-h intervals & $\begin{array}{l}25 \mathrm{~N}\left(25 \mathrm{mg} \mathrm{N} \mathrm{kg}^{-1} \text { soil }\right) \\
75 \mathrm{~N}\left(75 \mathrm{mg} \mathrm{N} \mathrm{kg}^{-1} \text { soil }\right) \\
150 \mathrm{~N}\left(150 \mathrm{mg} \mathrm{N} \mathrm{kg}^{-1} \text { soil }\right)\end{array}$ \\
\hline $\begin{array}{l}0.5 \mathrm{FC} 48 \mathrm{~h} \\
\text { Watered every } 48 \mathrm{~h} \text { from } 5 \text { to } 8 \%\end{array}$ & 48-h intervals & $\begin{array}{l}25 \mathrm{~N}\left(25 \mathrm{mg} \mathrm{N} \mathrm{kg}^{-1} \text { soil }\right) \\
75 \mathrm{~N}\left(75 \mathrm{mg} \mathrm{N} \mathrm{kg}^{-1} \text { soil }\right) \\
150 \mathrm{~N}\left(150 \mathrm{mg} \mathrm{N} \mathrm{kg}^{-1} \text { soil }\right)\end{array}$ \\
\hline $\begin{array}{l}\text { Wet/dry cycle } \\
\text { Dried down to } 8 \% \text {, then re-wet to } 16 \% \text { for } 7 \text { days (see Fig. 2) }\end{array}$ & Irregular & $\begin{array}{l}25 \mathrm{~N}\left(25 \mathrm{mg} \mathrm{N} \mathrm{kg}^{-1} \text { soil }\right) \\
75 \mathrm{~N}\left(75 \mathrm{mg} \mathrm{N} \mathrm{kg}^{-1} \text { soil }\right) \\
150 \mathrm{~N}\left(150 \mathrm{mg} \mathrm{N} \mathrm{kg}^{-1} \text { soil }\right)\end{array}$ \\
\hline
\end{tabular}




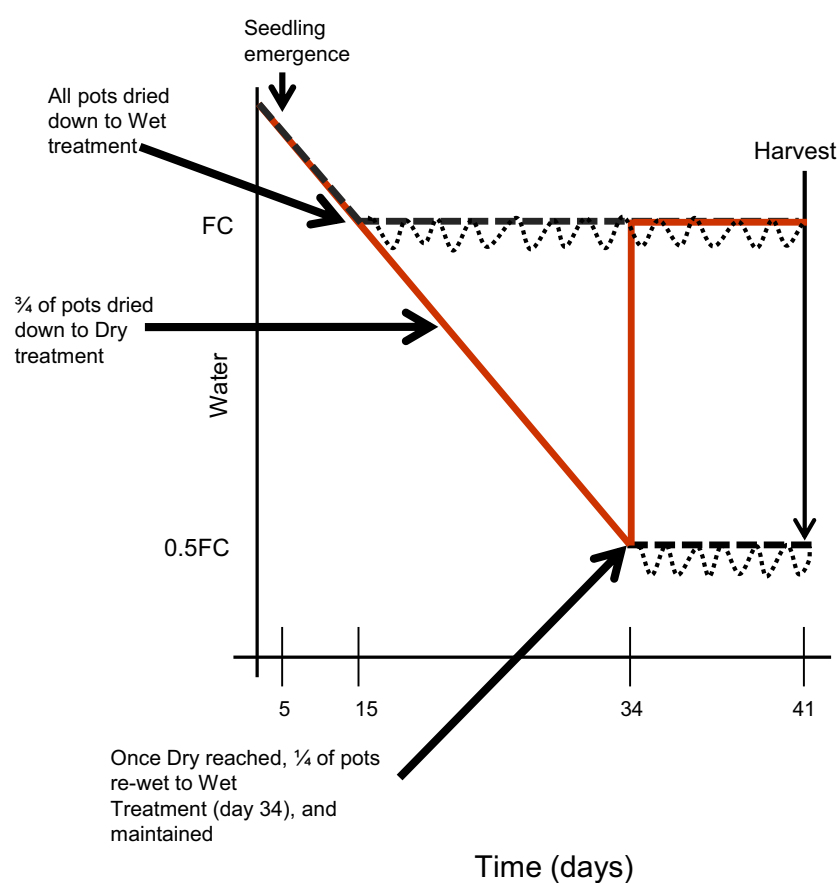

Fig. 2 Schematic diagram of the five experimental water treatments, set up on the DroughtSpotter

with a stainless-steel head (CHRO-40-BLP or CHRO-200BLRP depending on the size of plant biomass) for 1-2 min. The ground samples were analysed for total nitrogen (TN) by dry combustion (http://www.apal.com.au/; Rayment and Lyons 2011).

\subsection{Soil Sampling and Analysis}

At harvest, after root excavation, the soil from an individual pot was thoroughly mixed to ensure homogeneity, a sample of approximately $100 \mathrm{~g}$ was taken from each pot and divided into two sub-samples. One sub-sample was used for analysis of $\mathrm{NH}_{4}{ }^{+}-\mathrm{N}$ and another for analysis of $\mathrm{NO}_{3}{ }^{-}-\mathrm{N}$, as described previously (see section 2.1.).

\subsection{Statistical Analysis}

The experiment used a split-plot design for each genotype, with each genotype located on different sides of the gravimetric system. There were four replicates per genotype of the 15 combinations of $\mathrm{N}$ addition (three levels) and soil watering treatments (five levels); thus, there were 120 pots in total (with additional 21 pots set up as plant-free controls). The water treatments were assigned to the main plots and the nitrogen treatments to the subplots. A split-plot factorial ANOVA was performed on the 60 values of each variable for each genotype (Online Resource Table S2). In these analyses, blocks, whole plots and subplots were represented by replicates, water treatment and plants (detailing nitrogen treatment), respectively. The data for each of the variables were tested for normality prior to analysis, and some were treated by applying either natural $\log$ or square root functions where appropriate (see Online Resource Table S3). Response variables included in the analysis were shoot and root biomass, soil $\mathrm{NH}_{4}{ }^{+}-\mathrm{N}$ and, $\mathrm{NO}_{3}{ }^{-}-\mathrm{N}$ content, shoot total $\mathrm{N}$ and soil total $\mathrm{N}$. Where the ANOVA revealed a treatment effect $(p<0.05)$, differences between individual treatments were identified using least significant differences of means at the $5 \%$ level (LSD of means) tests. The statistical analyses were performed using GenStat 19th Edition.

\section{Results}

\subsection{Plant Biomass}

Biomass accumulation and distribution between shoots and roots differed between different water and $\mathrm{N}$ treatments for both genotypes (Fig. 3).

For Gladius, the shoot dry mass (Fig. 3a) differed between watering treatments irrespective of $\mathrm{N}$ addition treatment. Plants with access to the full soil water capacity (FC and to a lesser extent FC $48 \mathrm{~h}$ ) had significantly higher above-ground biomass than plants with access to half the soil water capacity $(0.5 \mathrm{FC}$ and $0.5 \mathrm{FC} 48 \mathrm{~h}$ ) and the wet/dry cycling treatment. In contrast, Gladius root dry weights were influenced by both water and $\mathrm{N}$ (significant interaction, $p<0.05$ ). Belowground biomass increased (to varying extents) with increasing $\mathrm{N}$ in all water treatments, except the FC $48 \mathrm{~h}$ treatment where root dry weights were greatest in the intermediate $\mathrm{N}$ addition treatment $(75 \mathrm{~N})$. For Kukri, both water and $\mathrm{N}$ addition treatments had a significant main effect on both shoot and root dry weights (Fig. 3b). Kukri shoot dry weight was higher in the wetter treatments ( $\mathrm{FC}$ and $\mathrm{FC} 48 \mathrm{~h}$ ) than the drier treatments (0.5FC, $0.5 \mathrm{FC} 48 \mathrm{~h}$, wet/dry) irrespective of $\mathrm{N}$ treatment. With regard to $\mathrm{N}, 25 \mathrm{~N}$ had less biomass than $75 \mathrm{~N}$ and $150 \mathrm{~N}\left(\mathrm{~N} p<0.01,25 \mathrm{~N}^{\mathrm{a}} 75 \mathrm{~N}^{\mathrm{b}} 150 \mathrm{~N}^{\mathrm{b}}\right)$. With Kukri roots, all water treatments resulted in more biomass with wetter water treatments, regardless of the $\mathrm{N}$ treatments. The FC treatment resulted in particularly large root systems, and $0.5 \mathrm{FC} 48 \mathrm{~h}$ treatment had the smallest root systems.

Specific root length (Fig. 4) was highly variable among water treatments for both varieties. For Gladius, there was an interaction between water and $\mathrm{N}$ addition treatments, with specific root length generally greatest in the low $\mathrm{N}$ addition treatment, and especially so in the $0.5 \mathrm{FC} 48 \mathrm{~h}$ and wet/dry treatments (Fig. 4a). Whilst Kukri showed a similar pattern overall, only the main effect of $\mathrm{N}$ addition treatment was significant with specific root length highest in the $25 \mathrm{~N}$ treatment, lowest in $150 \mathrm{~N}$ and intermediate in the $75 \mathrm{~N}$ treatment (Fig. 4b). However, it is important to note that there was little variation within the treatments for Kukri. 
Fig. 3 Average shoot dry weight (pale shading, above $x$-axis) and root dry weight (dark shading, below $x$-axis) for Gladius (a) and Kukri (b); with five water treatments (FC (field capacity); FC 48 h, 0.5FC, 0.5 FC 48 h, wet/ dry) and three nitrogen treatments: $25 \mathrm{~N}\left(25 \mathrm{mg} \mathrm{kg}^{-1}\right.$ of $\mathrm{N}), 75 \mathrm{~N}\left(75 \mathrm{mg} \mathrm{kg}^{-1}\right.$ of $\left.\mathrm{N}\right)$, $150 \mathrm{~N}$ (150 $\mathrm{mg} \mathrm{kg}^{-1}$ of $\left.\mathrm{N}\right)$. Values are presented as mean values \pm SE. Using ANOVA and LSD of means $5 \%$ level, means with different letters are shown to be significantly different $(p<0.05$ or 0.001 ). Gladius (a) shows significant main effect for shoots, letters above bars (water $p<0.05$; $\mathrm{N}$ not significant); for roots, water $\times \mathrm{N} p<0.05$, letters above bars. For Kukri shoots (b), main effects present for both water and $\mathrm{N}$, letters for water above bars (water $p<0.001$ with $\mathrm{N} p<0.05,25 \mathrm{~N}^{\mathrm{a}}$ $\left.75 \mathrm{~N}^{\mathrm{b}} 150 \mathrm{~N}^{\mathrm{c}}\right)$. For Kukri roots, main effects were present for water $p<0.001$ (letters above bar) and $\mathrm{N}\left(p<0.05 ; 25 \mathrm{~N}^{\mathrm{a}} 75 \mathrm{~N}^{\mathrm{b}}\right.$ $\left.150 \mathrm{~N}^{\mathrm{a}}\right)$
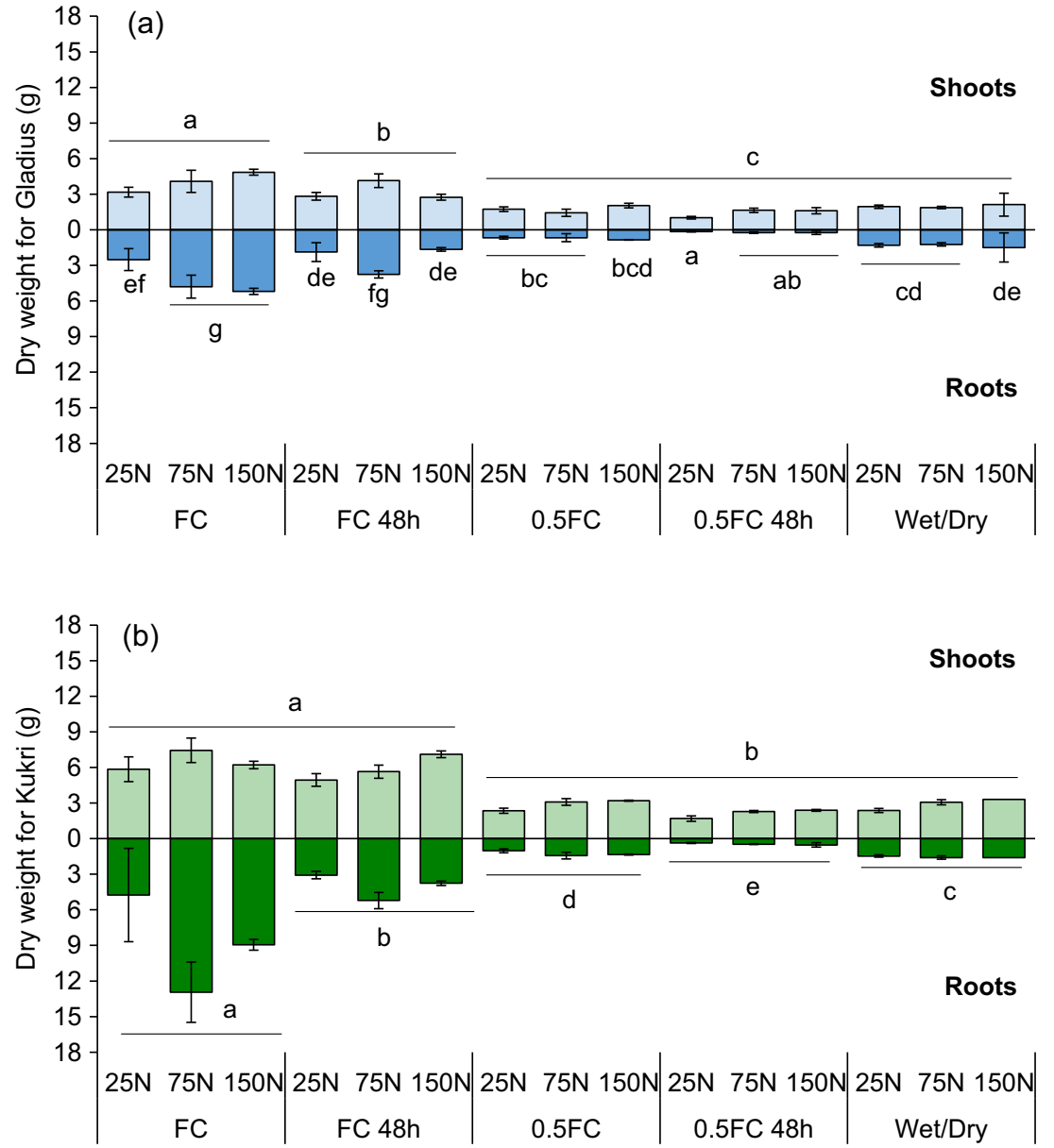

\subsection{Plant Water Use}

In addition to providing a precise watering regime, DroughtSpotter provided the amount of water applied to each pot over time (by weight). The amount of water applied per day was used to calculate cumulative water applied per pot for both varieties (see Online Resource Fig. S1, S2), with average total cumulative water shown in Online Resource Table S4. The plant-free controls (watered only to FC) received a cumulative total of $645.7 \mathrm{~mL}$ water over 6 weeks, compared to a cumulative total of $1488.4 \mathrm{~mL}$ water for the pots with wheat. From this, we calculated the wheat pots watered to FC had approximately an extra $842.7 \mathrm{~mL}$ of water over the course of the experiment.

Water use efficiency, i.e. the amount of plant (shoot + root) biomass ( $\mathrm{g}$ dry weight) produced per unit water $(\mathrm{L})$ applied (which includes both evaporation and transpiration), was calculated (Fig. 5). For Gladius, there was a significant interaction between water and $\mathrm{N}$, with water use efficiency significantly lower in the $0.5 \mathrm{FC} 48 \mathrm{~h} \times 25 \mathrm{~N}$ treatment compared to the rest of the treatments (Fig. 5a). However, with Kukri (Fig. 5b), only water was significant as the main effect (regardless of N). FC water treatment resulted in the highest water use efficiency $(p<0.05)$.

\subsection{Nitrogen Dynamics}

Plant $\mathrm{N}$ concentrations were affected by both water and $\mathrm{N}$ addition treatments (Fig. 6). Overall, shoot total $\mathrm{N}$ concentration did not differ greatly between treatments. However, there was a significant water by $\mathrm{N}$ interaction for Gladius (Fig. 6a). For Kukri, shoot total $\mathrm{N}$ concentration did not differ between water treatments $\mathrm{FC}, 0.5 \mathrm{FC}$ and $0.5 \mathrm{FC} 48 \mathrm{~h}$ (regardless of $\mathrm{N}$ addition treatment), but shoot total $\mathrm{N}$ concentration was significantly higher for the wet/dry treatments, regardless of $\mathrm{N}$ addition treatment (Fig. 6b).

Mineral $\mathrm{N}$ (the sum of $\mathrm{NO}_{3}{ }^{-}-\mathrm{N}$ and $\mathrm{NH}_{4}{ }^{+}-\mathrm{N}$ left in the soil at harvest) was highly variable within water and $\mathrm{N}$ treatments, and between genotypes (Fig. 7). For both genotypes, there was a significant interaction between water and $\mathrm{N}$ addition treatments. In the case of Gladius (Fig. 7a), the amount of mineral $\mathrm{N}$ left in the soil was generally highest for the $150 \mathrm{~N}$ (150 mg of $\mathrm{N} \mathrm{kg}^{-1}$ of soil) addition treatments, with the FC treatment as the exception. Mineral $\mathrm{N}$ level for Kukri (Fig. 7b) 

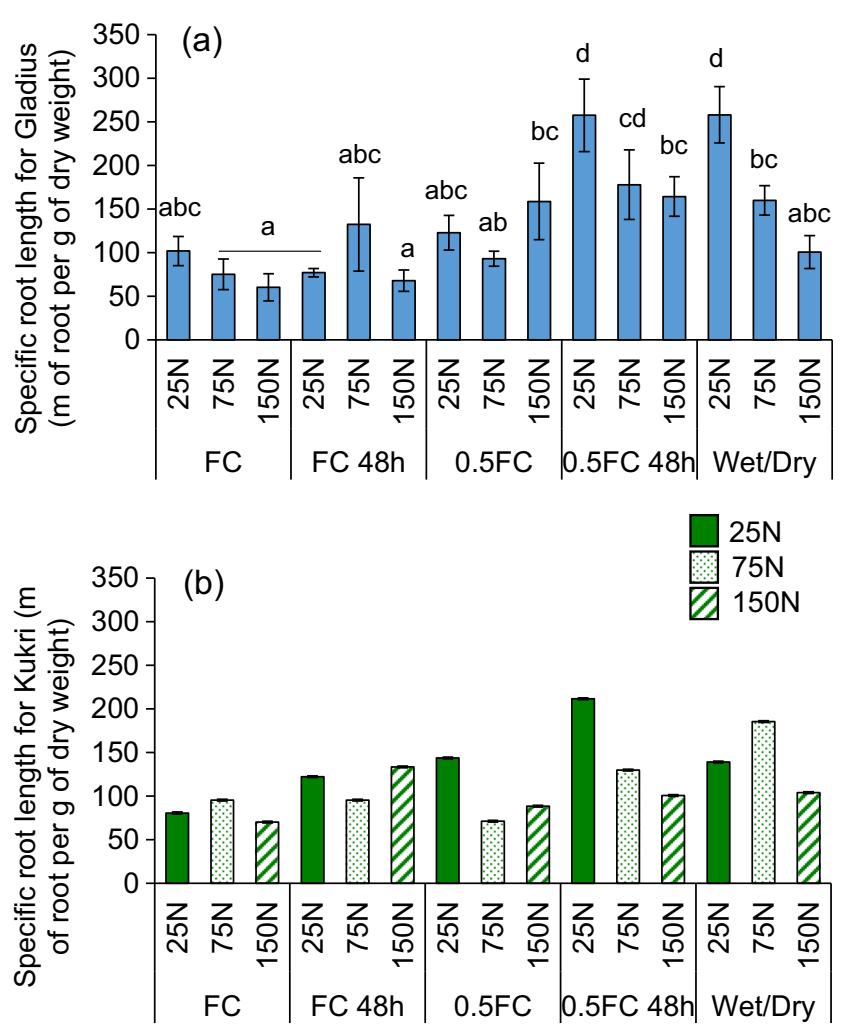

Fig. 4 Mean specific root length for Gladius (a) and Kukri (b) under five water treatments (FC (field capacity), FC $48 \mathrm{~h}, 0.5 \mathrm{FC}, 0.5 \mathrm{FC} 48 \mathrm{~h}$, wet/ dry) and three $\mathrm{N}$ treatments: $25 \mathrm{~N}\left(25 \mathrm{mg} \mathrm{kg}^{-1}\right.$ of $\left.\mathrm{N}\right), 75 \mathrm{~N}\left(75 \mathrm{mg} \mathrm{kg}^{-1}\right.$ of $\mathrm{N}), 150 \mathrm{~N}\left(150 \mathrm{mg} \mathrm{kg}^{-1}\right.$ of $\left.\mathrm{N}\right)$. Values are presented as mean values $\pm \mathrm{SE}$, $n=4$. Using ANOVA and LSD of means $5 \%$ level, means with different letters are shown to be significantly different. For Gladius (a), water $\times \mathrm{N}$ interaction present, $p<0.05$. For Kukri (b), only main effect of $\mathrm{N}$ present $\left(p<0.05,25 \mathrm{~N}^{\mathrm{b}} 75 \mathrm{~N}^{\mathrm{ab}} 150 \mathrm{~N}^{\mathrm{a}}\right)$, where bars of a different pattern are different from each other

was similar to Gladius and was also generally higher for the $150 \mathrm{~N}$ treatment. Overall, mineral $\mathrm{N}$ for Kukri was generally lower in the FC and FC $48 \mathrm{~h}$ treatments. Finally, the soils were $\mathrm{NO}_{3}{ }^{-}$dominated with $\mathrm{NO}_{3}{ }^{-}-\mathrm{N}$ values up to 13 times greater than $\mathrm{NH}_{4}{ }^{+}-\mathrm{N}$ concentrations (see Online Resource Table $\mathrm{S} 1$ ).

\section{Discussion}

The DroughtSpotter automated irrigation system allowed a precise level of control over watering and fine-scale water use data. The ability to simulate rainfall or irrigation scenarios coupled with variable $\mathrm{N}$ will benefit precision agriculture by improving our understanding of resource use efficiency. Water and $\mathrm{N}$ treatments, whether in combination or alone, had significant impacts on plant water use, biomass accumulation, $\mathrm{N}$ uptake and soil $\mathrm{N}$ dynamics. Biomass accumulation, especially in roots, increased under lower $\mathrm{N}$ and wetter conditions, and longer, thinner roots were produced under drier conditions.
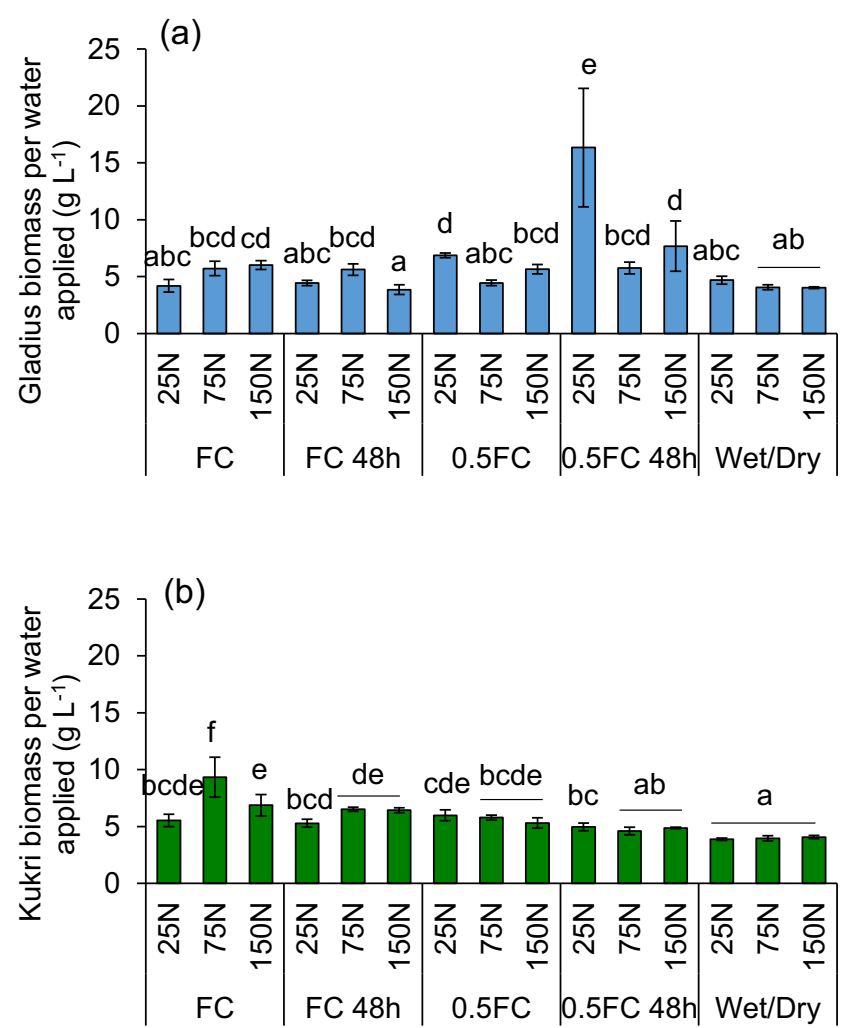

Fig. 5 Average water use efficiency (WUE) for five treatments (FC (field capacity), FC $48 \mathrm{~h}, 0.5 \mathrm{FC}, 0.5 \mathrm{FC} 48 \mathrm{~h}$, wet/dry) and three nitrogen treatments: $25 \mathrm{~N}\left(25 \mathrm{mg} \mathrm{kg}^{-1}\right.$ of $\left.\mathrm{N}\right), 75 \mathrm{~N}\left(75 \mathrm{mg} \mathrm{kg}^{-1}\right.$ of $\left.\mathrm{N}\right), 150 \mathrm{~N}$ $\left(150 \mathrm{mg} \mathrm{kg}^{-1}\right.$ of $\left.\mathrm{N}\right)$. Error bars represent the standard error of the mean (SE), $n=4$. Bars with different letters are significantly different $(p<0.05$ or 0.001 , LSD of means $5 \%$ level). For Gladius (a) and Kukri (b), a significant interaction of water $\times \mathrm{N} p<0.05$ present (letters of significance above bars)

Under optimal conditions, wheat responses can differ depending on genotype. Gladius root biomass increased with increasing $\mathrm{N}$ when water content was held at FC. In the field, Gladius has performed well under water stressed conditions and better than other commercial varieties; therefore, this could aid its response to water variability (Bennett et al. 2012; Izanloo et al. 2008). For Kukri, the higher root (and shoot) growth observed under $75 \mathrm{~N}$, could be a result of Kukri's higher $\mathrm{N}$ use efficiency, thus enabling it to adapt and produce more biomass growth under lower $\mathrm{N}$ levels. This pattern (greatest biomass at $75 \mathrm{~N}$ ) was also present under $\mathrm{FC} 48 \mathrm{~h}$ for both varieties. It is possible that FC $48 \mathrm{~h}$ became a potential stress condition as water was not constant; therefore, plants responded by producing longer roots (not necessarily thinner) to access both $\mathrm{N}$ and water.

Although water was a limiting factor, the timing of watering affected the ability of the plants to adapt to water and/or N variability more. This is shown by $0.5 \mathrm{FC} 48 \mathrm{~h}$ plants having the smallest root:shoot ratios for both varieties, because both quantity and frequency of watering imposed some limitation on growth. Also, the $0.5 \mathrm{FC} 48 \mathrm{~h}$ plants were smaller than wet/dry plants and $0.5 \mathrm{FC}$ plants for Kukri. There 

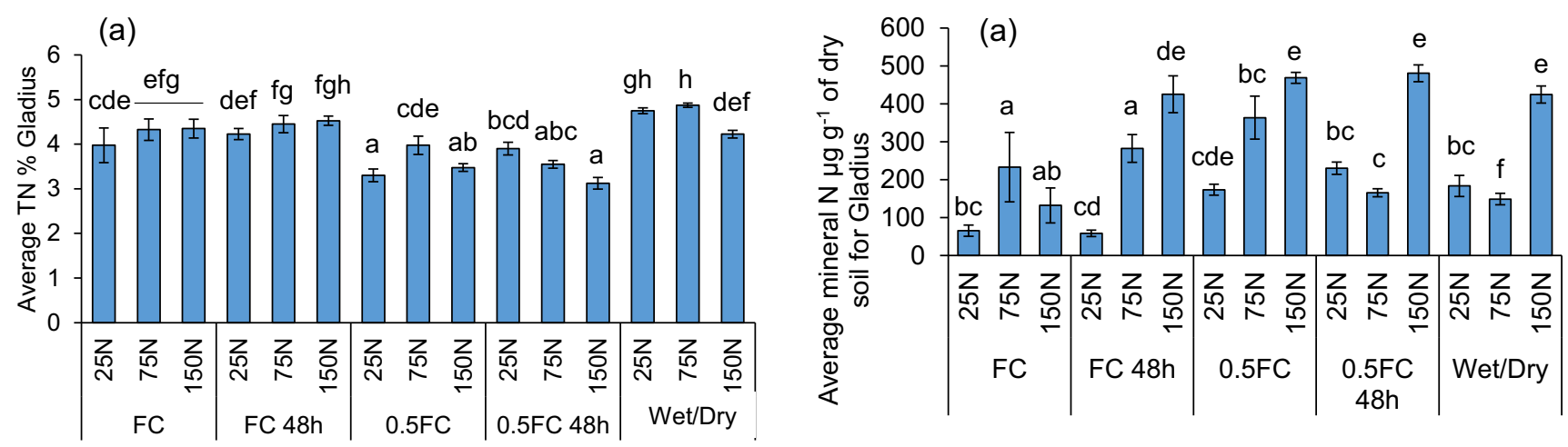

(b)

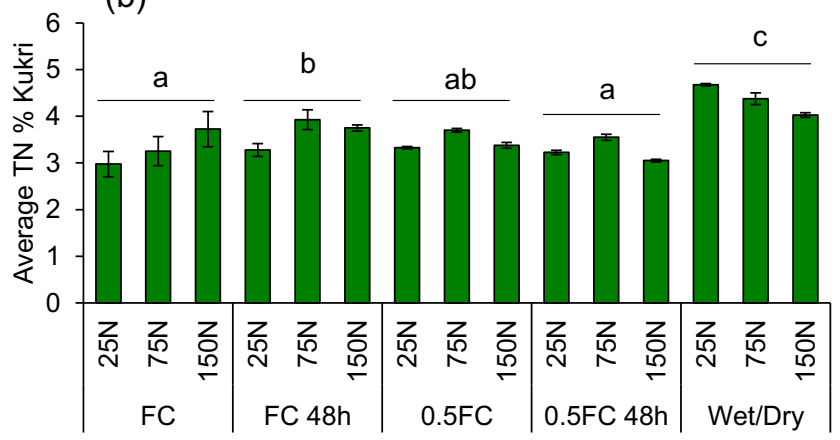

Fig. 6 Average shoot total $\mathrm{N}$ as a percentage of dry weight for Gladius (panel a) and Kukri (panel b) under five water treatments (FC (field capacity), FC $48 \mathrm{~h}, 0.5 \mathrm{FC}, 0.5 \mathrm{FC} 48 \mathrm{~h}$, wet/dry), and three $\mathrm{N}$ treatments: $25 \mathrm{~N}\left(25 \mathrm{mg} \mathrm{kg}^{-1}\right.$ of $\left.\mathrm{N}\right), 75 \mathrm{~N}\left(75 \mathrm{mg} \mathrm{kg}^{-1}\right.$ of $\left.\mathrm{N}\right), 150 \mathrm{~N}$ $\left(150 \mathrm{mg} \mathrm{kg}^{-1}\right.$ of $\left.\mathrm{N}\right)$. Values are presented as mean values $\pm \mathrm{SE}, n=4$. Using ANOVA and LSD of means 5\% level, means with different letters are shown to be significantly different. For Gladius (a), water $\times \mathrm{N}$ interaction present $(p<0.05)$, letters above bars. For Kukri (b), main effects of water shown $(p<0.001)$, letters above bars, no main effect for $\mathrm{N}$

have been several studies that explore the pulsed water effect, i.e. how the frequency as well as the quantity of water influence plant growth. For example, Ivans et al. (2003) found that with just one simulated rainfall event, plant acquisition of $\mathrm{N}$ was stimulated encouraging higher root $\mathrm{N}$ uptake. It is possible that plants under the wet/dry treatment had more roots before the dry-down happened, shown by less root biomass for $0.5 \mathrm{FC}$ plants than wet/dry. Gibson-Forty et al. (2016) showed that a $50 \%$ reduction in rainfall quantity had a more severe impact on growth than a reduction in frequency. However, different magnitudes or frequencies of pulsed water supply impact plants differently, even when water quantity remains the same (Padilla et al. 2013). The frequency and quantity of water also impacted soil moisture and drying dynamics. This is consistent with other studies, where wettingdrying events or pulsed water events changed the way soil dries or re-wets (Fierer and Schimel 2002; Padilla et al. 2013). Having frequent watering but reduced quantity resulted in a drier soil over the short period of time between watering (the change in soil moisture content can be monitored using

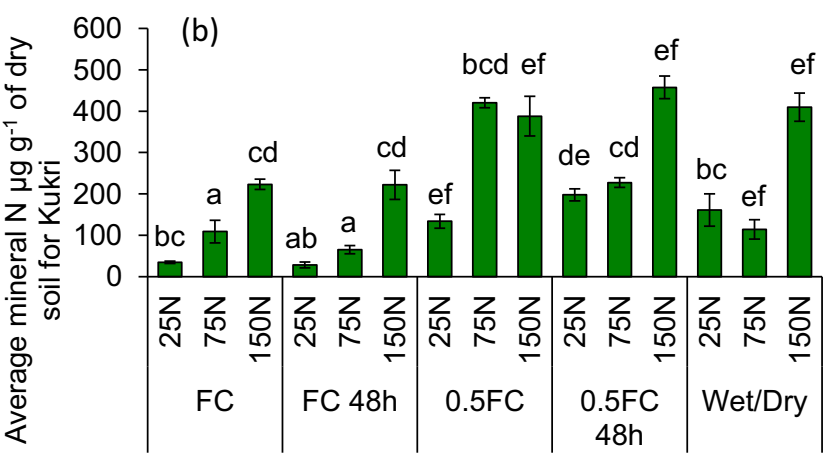

Fig. 7 Total mineral $\mathrm{N}$ concentrations comprising of $\mathrm{NO}_{3}{ }^{-}{ }^{-} \mathrm{N}$ and $\mathrm{NH}_{4}{ }^{+}-$ $\mathrm{N} \mu \mathrm{g} \mathrm{g}^{-1}$ dry soil for Gladius (a) and Kukri (b) under five water treatments (FC (field capacity), FC $48 \mathrm{~h}, 0.5 \mathrm{FC}, 0.5 \mathrm{FC} 48 \mathrm{~h}$, wet/dry) and three $\mathrm{N}$ treatments: $25 \mathrm{~N}\left(25 \mathrm{mg} \mathrm{kg}^{-1}\right.$ of $\left.\mathrm{N}\right), 75 \mathrm{~N}\left(75 \mathrm{mg} \mathrm{kg}^{-1}\right.$ of $\left.\mathrm{N}\right)$, $150 \mathrm{~N}\left(150 \mathrm{mg} \mathrm{kg}^{-1}\right.$ of $\left.\mathrm{N}\right)$. Error bars represent the standard error of the mean (SE), $n=4$. Significant interactions of water $\times \mathrm{N}$ are represented as letters above bars, calculated using ANOVA and LSD of means. Means with different letters are significantly different $(p<0.001$, LSD of means $5 \%$ level). Gladius $(\mathbf{a} ; p<0.05)$ and Kukri $(\mathbf{b} ; p<0.01)$ showed a significant interaction of water $\times \mathrm{N}(p<0.05)$, letters above bars

the automated gravimetric watering system), whereas less frequent watering resulted in wetter soil conditions for a longer period of time, most likely due to the larger water pulses (Padilla et al. 2013). These studies highlights that frequency of watering is vitally important in plant biomass allocation, but none of these studies have looked at truly constant watering, where water content is precisely maintained more frequently than $24 \mathrm{~h}$. Under variable water conditions $(0.5 \mathrm{FC}$, $0.5 \mathrm{FC} 48 \mathrm{~h}$, wet/dry), specific root length increased, with roots getting longer and thinner to access water or $\mathrm{N}$ pools at depth, a strategy that is important to access nutrients and water at depth in drying soils. In this case, it would be to access soil moisture increasing further down the pot (Fig. S3); in this way, this pot study may be reflecting an important feature of soil moisture availability in the field. Additionally, producing longer, thinner roots reduces the mean root diameter, creating a larger root surface (Fitter 2002). This enables the plant to maximise water and $\mathrm{N}$ uptake, particularly under resource limitation. Although specific root length does not quantify the actual thickness of the root, there are two relevant 
assumptions: (1) the length of the root is proportional, or related to resource acquisition, and (2) root biomass or the weight is proportional to the maintenance of the root or plant (Eissenstat and Yanai 1997; Ostonen et al. 2007). If a plant has thinner and longer roots, it becomes less expensive for the plant to maintain these roots, than if they were thicker (Withington et al. 2006).

Mineral $\mathrm{N}$ analysis showed $\mathrm{NO}_{3}{ }^{-}-\mathrm{N}$ values were up to 13 times greater than $\mathrm{NH}_{4}{ }^{+}-\mathrm{N}$ concentrations. The amount of mineral $\mathrm{N}$ left in the soil differed greatly between genotypes, with less mineral $\mathrm{N}$ available under $\mathrm{FC}$ or $\mathrm{FC} 48 \mathrm{~h}$ conditions with Kukri than Gladius. This has been tentatively interpreted as being due to the varieties as opposed to the environmental conditions of the glasshouse; therefore, further experiments would be needed to confirm this. However, the lower concentration of mineral $\mathrm{N}$ available for Kukri under high moisture content suggests that water was the main driver for $\mathrm{N}$ uptake. Soil type is also important with respect to nutrient availability. The soil had a high organic matter content, which suggests greater nutrient availability. A pulse of water, i.e. $48 \mathrm{~h}$ watering, flushes the soil system, re-wetting the soil and allowing for pockets of previously inaccessible urea to become mobile again, encouraging microbial activity and mineralisation of urea into plant-available forms of $\mathrm{N}$ (Cui and Caldwell 1997; Gordon et al. 2008; Ivans et al. 2003).

Plant tissue $\mathrm{N}$ was generally uniform across the treatments suggesting good internal $\mathrm{N}$ homeostasis. Overall, plant total $\mathrm{N}$ ranged between 3 and $5 \%$, which is well above the critically $\mathrm{N}$ deficient range for wheat of $1.28-1.39 \%$ (as suggested by Reuter and Robinson 1997). Our study highlights how carbon allocation in roots is also affected by $\mathrm{N}$ availability. A reduction in soil $\mathrm{N}$ content can reduce root uptake of $\mathrm{N}$ and subsequent $\mathrm{N}$ remobilisation; however, to compensate for low $\mathrm{N}$ accumulation, research shows an increase in $\mathrm{N}$ remobilisation, especially post-anthesis and at grain filling (Masoni et al. 2008). Under high soil $\mathrm{NO}_{3}{ }^{-} \mathrm{N}$ concentrations, the shoots dominate assimilation of $\mathrm{NO}_{3}{ }^{-} \mathrm{N}$, but this is an energy-intensive process. Under low soil $\mathrm{NO}_{3}{ }^{-}-\mathrm{N}$ concentrations, root $\mathrm{C}: \mathrm{N}$ ratio becomes higher, so most of the $\mathrm{NO}_{3}{ }^{-} \mathrm{N}$ is taken up and functions as a signal molecule to nitrate transporters, affecting auxin production, which regulates root growth (Krouk et al. 2010). Such conditions are likely to favour formation of lateral roots (Zhang et al. 1999). As a result, very little of the assimilated $\mathrm{NO}_{3}{ }^{-} \mathrm{N}$ is translocated to the shoots. Obviously, the $\mathrm{C}: \mathrm{N}$ ratio and what plants determine as a low or high $\mathrm{NO}_{3}^{-}-\mathrm{N}$ level differs between species (Wang and Ruan 2016; Zheng 2009). If soil $\mathrm{NO}_{3}{ }^{-}-\mathrm{N}$ concentrations increased (root $\mathrm{C}$ decreases overall), more $\mathrm{NO}_{3}{ }^{-}-\mathrm{N}$ could be translocated to the shoots. This result mirrors what was shown by Bloom et al. (1993), who found that with higher concentrations of $\mathrm{NO}_{3}{ }^{-}-\mathrm{N}$ and $\mathrm{NH}_{4}{ }^{+} \mathrm{-N}$, root growth was significantly lowered, due to a smaller root able to acquire enough $\mathrm{N}$ for its root function, and send surplus to the shoot. Therefore, it would be unnecessary to produce more root biomass, as this would require more energy reallocation of sugars from the shoots to the roots, potentially causing a carbon deficit in the shoots.

\section{Conclusions}

Our observation of less frequent watering having a more negative effect on plant growth compared to a reduction in water quantity has important implications for agriculture, as most recent climate change projections indicate significant variations in rainfall frequency are likely, and issues of water scarcity already exist in many areas of the globe. Such findings are key for future agricultural management of water. Evidence of an interaction between water and $\mathrm{N}$ is important, because it highlights the effect on $\mathrm{C}$ allocation. The changes to root thickness, even when root biomass remained the same, show it is not necessary to have the highest inputs of water and $\mathrm{N}$ in order to achieve healthy plants. We found large differences between precision-controlled constant watering versus 48 -h watering intervals, which show that attempting to maintain water levels manually as is undertaken in most similar studies may alter plant physiology, soil water physical properties and nutrient cycling processes. This has profound implications for future research in this area and highlights how watering frequency can have a more negative impact on plant growth than the watering amount. However, in irrigated systems, alternating between a high watering amount and a period of no water (i.e. wet/dry cycle) may be a way to encourage plants to adapt to small stresses and still have healthy growth, in addition to conserving water. This knowledge supports future farming irrigation practices encouraging less water and nitrogen use, leading to several potential environmental and socioeconomic benefits. Further identifying root and shoot traits that may improve plant survival under moderate to extreme resource limitation could also be introduced into breeding programmes.

Supplementary Information The online version contains supplementary material available at https://doi.org/10.1007/s42729-021-00467-3.

Acknowledgements We would like to acknowledge the use of the facilities, and scientific and technical assistance of the Australian Plant Phenomics Facility, which is supported by the Australian Government's National Collaborative Research Infrastructure Strategy (NCRIS), and thank them for providing a Postgraduate Student Internship Award to $\mathrm{OHC}$ to undertake this research. We thank Lidia Mischis, Nicole Bond and Fiona Groskreutz for their role in soil preparation and potting. We also thank Mattias Solomon, Dr. Christina Asanopoulos, Binh Thi Thanh Tran and Rebecca Stonor for their assistance with harvesting. This research was funded via the award of a Beacon of Enlightenment Scholarship to OHC as part of a partnership between the University of Adelaide and the University of Nottingham.

Materials Availability The materials can be made available upon request. 
Code Availability Not applicable.

Authors' Contributions Conceptualisation: Olivia Cousins, Trevor Garnett, Amanda Rasmussen, Sacha Mooney, Ronald Smernik, Chris Brien, Timothy Cavagnaro.

Methodology: Olivia Cousins, Trevor Garnett, Amanda Rasmussen, Sacha Mooney, Ronald Smernik, Chris Brien, Timothy Cavagnaro.

Formal analysis and investigation: Olivia Cousins, Trevor Garnett, Chris Brien.

Writing - original draft preparation: Olivia Cousins.

Writing - review and editing: Trevor Garnett, Amanda Rasmussen, Sacha Mooney, Ronald Smernik, Chris Brien, Timothy Cavagnaro.

Funding acquisition: Olivia Cousins, Trevor Garnett; Amanda Rasmussen, Sacha Mooney, Ronald Smernik, Timothy Cavagnaro. Resources: Trevor Garnett, Chris Brien, Timothy Cavagnaro.

Supervision: Trevor Garnett, Amanda Rasmussen, Sacha Mooney, Ronald Smernik, Timothy Cavagnaro.

Funding This work was supported by the Australian Government's National Collaborative Research Infrastructure Strategy (NCRIS); and a Beacon of Enlightenment Scholarship as part of a partnership between the University of Adelaide and the University of Nottingham. SJM was funded by NUCLEUS: a virtual joint centre to deliver enhanced NUE via an integrated soil-plant systems approach for the UK and Brazil; Biotechnology and Biological Sciences Research Council [grant number BB/N013201/1].

Data Availability The data can be made available upon request.

\section{Declarations}

Conflict of Interest The authors have no conflict of interest to declare that are relevant to the content of this article.

Open Access This article is licensed under a Creative Commons Attribution 4.0 International License, which permits use, sharing, adaptation, distribution and reproduction in any medium or format, as long as you give appropriate credit to the original author(s) and the source, provide a link to the Creative Commons licence, and indicate if changes were made. The images or other third party material in this article are included in the article's Creative Commons licence, unless indicated otherwise in a credit line to the material. If material is not included in the article's Creative Commons licence and your intended use is not permitted by statutory regulation or exceeds the permitted use, you will need to obtain permission directly from the copyright holder. To view a copy of this licence, visit http://creativecommons.org/licenses/by/4.0/.

\section{References}

Araya YN, Gowing DJ, Dise N (2010) A controlled water-table depth system to study the influence of fine-scale differences in water regime for plant growth. Aquat Bot 92:70-74. https://doi.org/10.1016/ j.aquabot.2009.10.004

Asseng S, Ritchie JT, Smucker AJM, Robertson MJ (1998) Root growth and water uptake during water deficit and recovering in wheat. Plant Soil 201:265-273. https://doi.org/10.1023/A:1004317523264

Austin AT, Yahdjian L, Stark JM, Belnap J, Porporato A, Norton U, Ravetta DA, Schaeffer SM (2004) Water pulses and biogeochemical cycles in arid and semiarid ecosystems. Oecologia 141:221-235. https://doi.org/10.1007/s00442-004-1519-1

Baker KF (1957) The U.C. system for producing healthy container-grown plants. Agricultural Publications, University of California, U.S.A
Bennett D, Reynolds M, Mullan D, Izanloo A, Kuchel H, Langridge P, Schnurbusch T (2012) Detection of two major grain yield QTL in bread wheat (Triticum aestivum L.) under heat, drought and high yield potential environments. Theor Appl Genet 125:1473-1485. https://doi.org/10.1007/s00122-012-1927-2

Bijay-Singh, Yadvinder-Singh, Sekhon GS (1995) Fertilizer-N use efficiency and nitrate pollution of groundwater in developing countries. J Contam Hydrol 20:167-184. https://doi.org/10.1016/01697722(95)00067-4

Bloom AJ, Chapin FS, Mooney HA (1985) Resource limitation in plants an economic analogy. Annu Rev Ecol Syst 16:363-392. https://doi. org/10.1146/annurev.es.16.110185.002051

Bloom AJ, Jackson LE, Smart DR (1993) Root growth as a function of ammonium and nitrate in the root zone. Plant Cell Environ 16:199 206. https://doi.org/10.1111/j.1365-3040.1993.tb00861.x

Burger M, Jackson LE, Lundquist EJ, Louie DT, Miller RL, Rolston DE, Scow KM (2005) Microbial responses and nitrous oxide emissions during wetting and drying of organically and conventionally managed soil under tomatoes. Biol Fertil Soils 42:109-118. https://doi. org/10.1007/s00374-005-0007-z

Carstensen J, Andersen JH, Gustafsson BG, Conley DJ (2014) Deoxygenation of the Baltic Sea during the last century. Proc Natl Acad Sci 111:5628 LP-5625633. https://doi.org/10.1073/pnas. 1323156111

Cavagnaro TR (2016) Soil moisture legacy effects: impacts on soil nutrients, plants and mycorrhizal responsiveness. Soil Biol Biochem 95: 173-179. https://doi.org/10.1016/j.soilbio.2015.12.016

Comfort SD, Malzer GL, Busch RH (1988) Nitrogen fertilization of spring wheat genotypes: influence on root growth and soil water depletion. Agron J 80:114-120. https://doi.org/10.2134/ agronj1988.00021962008000010025x

Cossani CM, Slafer GA, Savin R (2010) Co-limitation of nitrogen and water, and yield and resource-use efficiencies of wheat and barley. Crop Pasture Sci 61:844-851. https://doi.org/10.1071/CP10018

Cousins OH, Garnett TP, Rasmussen A, Mooney SJ, Smernik RJ, Brien CJ, Cavagnaro TR (2020) Variable water cycles have a greater impact on wheat growth and soil nitrogen response than constant watering. Plant Sci 290:110146. https://doi.org/10.1016/j.plantsci. 2019.05.009

Cui M, Caldwell MM (1997) A large ephemeral release of nitrogen upon wetting of dry soil and corresponding root responses in the field. Plant Soil 191:291-299. https://doi.org/10.1023/A:1004290705961

Eissenstat DM, Yanai RD (1997) The ecology of root lifespan. Adv Ecol Res 27:1-60. https://doi.org/10.1016/S0065-2504(08)60005-7

Elazab A, Serret MD, Araus JL (2016) Interactive effect of water and nitrogen regimes on plant growth, root traits and water status of old and modern durum wheat genotypes. Planta 244:125-144. https:// doi.org/10.1007/s00425-016-2500-Z

Fierer N, Schimel JP (2002) Effects of drying-rewetting frequency on soil carbon and nitrogen transformations. Soil Biol Biochem 34: 777-787. https://doi.org/10.1016/S0038-0717(02)00007-X

Fitter A (2002) Characteristics and functions of root systems. In: Waisel Y, Eshel A, Kafkafi U (eds) Plant roots: the hidden half, 3rd edn. Marcel Dekker, Inc., New York, U.S.A., pp 21-50

Gibson-Forty EVJ, Barnett KL, Tissue DT, Power SA (2016) Reducing rainfall amount has a greater negative effect on the productivity of grassland plant species than reducing rainfall frequency. Funct Plant Biol 43:380-391. https://doi.org/10.1071/FP15174

Gordon H, Haygarth PM, Bardgett RD (2008) Drying and rewetting effects on soil microbial community composition and nutrient leaching. Soil Biol Biochem 40:302-311. https://doi.org/10.1016/j. soilbio.2007.08.008

Forster JC (1995) Methods in Applied Soil Microbiology and Biochemistry. San Diego, USA

Honsdorf N, March TJ, Berger B, Tester M, Pillen K (2014) Highthroughput phenotyping to detect drought tolerance QTL in wild 
barley introgression lines. PLoS One 9:e97047. https://doi.org/10. 1371/journal.pone.0097047

Hurd EA (1964) Root study of three wheat varieties and their resistance to drought and damage by soil cracking. Can J Plant Sci 44:240-248. https://doi.org/10.4141/cjps64-046

Ivans CY, Leffler AJ, Spaulding U, Stark JM, Ryel RJ, Caldwell MM (2003) Root responses and nitrogen acquisition by Artemisia tridentata and Agropyron desertorum following small summer rainfall events. Oecologia 134:317-324. https://doi.org/10.1007/ s00442-002-1089-z

Izanloo A, Condon AG, Langridge P, Tester M, Schnurbusch T (2008) Different mechanisms of adaptation to cyclic water stress in two South Australian bread wheat cultivars. J Exp Bot 59:3327-3346. https://doi.org/10.1093/jxb/ern199

Jensen KD, Beier C, Michelsen A, Emmett BA (2003) Effects of experimental drought on microbial processes in two temperate heathlands at contrasting water conditions. Appl Soil Ecol 24:165-176. https:// doi.org/10.1016/S0929-1393(03)00091-X

Ješko T, Navara J, Dekánková K (1997) Root growth and water uptake by flowering maize plants, under drought conditions. Biol Root Form Dev:270-271. https://doi.org/10.1007/978-1-4615-5403-5 53

Kastury F, Rahimi Eichi V, Enju A, Okamoto M, Heuer S, Melino V (2018) Exploring the potential for top-dressing bread wheat with ammonium chloride to minimize grain yield losses under drought. Soil Sci Plant Nutr 64:642-652. https://doi.org/10.1080/00380768.2018.1493341

Krouk G, Crawford NM, Coruzzi GM, Tsay Y-F (2010) Nitrate signaling: adaptation to fluctuating environments. Curr Opin Plant Biol 13:265-272. https://doi.org/10.1016/j.pbi.2009.12.003

López-Bellido L, López-Bellido RJ, Redondo R (2005) Nitrogen efficiency in wheat under rainfed Mediterranean conditions as affected by split nitrogen application. F Crop Res 94:86-97. https://doi.org/ 10.1016/j.fcr.2004.11.004

López-Bucio J, Cruz-Ramírez A, Herrera-Estrella L (2003) The role of nutrient availability in regulating root architecture. Curr Opin Plant Biol 6:280-287. https://doi.org/10.1016/S1369-5266(03)00035-9

Lynch J (1995) Root architecture and plant productivity. Plant Physiol 109:7-13. https://doi.org/10.1104/pp.109.1.7

Mahjourimajd S, Taylor J, Sznajder B, Timmins A, Shahinnia F, Rengel Z, Khabaz-Saberi H, Kuchel H, Okamoto M, Langridge P (2016) Genetic basis for variation in wheat grain yield in response to varying nitrogen application. PLoS One 11:e0159374. https://doi.org/10. 1371/journal.pone.0159374

Masoni A, Ercoli L, Mariotti M, Pampana S (2008) Nitrogen and phosphorus accumulation and remobilization of durum wheat as affected by soil gravel content. Cereal Res Commun 36:157-166. https://doi. org/10.1556/CRC.36.2008.1.16

Melino VJ, Fiene G, Enju A, Cai J, Buchner P, Heuer S (2015) Genetic diversity for root plasticity and nitrogen uptake in wheat seedlings. Funct Plant Biol 42:942-956. https://doi.org/10.1071/FP15041

Miranda KM, Espey MG, Wink DA (2001) A Rapid, Simple Spectrophotometric Method for Simultaneous Detection of Nitrate and Nitrite. Nitric Oxide 5:62-71

Newman EI (1966) A Method of Estimating the Total Length of Root in a Sample. J Appl Ecol 3:139

Ober ES, Werner P, Flatman E, Angus WJ, Jack P, Smith-Reeve L, Tapsell C (2014) Genotypic differences in deep water extraction associated with drought tolerance in wheat. Funct Plant Biol 41: 1078-1086. https://doi.org/10.1071/FP14094

Ostonen I, Püttsepp Ü, Biel C, Alberton O, Bakker MR, Lõhmus K, Majdi H, Metcalfe D, Olsthoorn AFM, Pronk A, Vanguelova E, Weih M, Brunner I (2007) Specific root length as an indicator of environmental change. Plant Biosyst - An Int J Deal with all Asp Plant Biol 141:426442. https://doi.org/10.1080/11263500701626069
Padilla FM, Aarts BHJ, Roijendijk YOA, de Caluwe H, Mommer L, Visser EJW, de Kroon H (2013) Root plasticity maintains growth of temperate grassland species under pulsed water supply. Plant Soil 369:377-386. https://doi.org/10.1007/s11104-012-1584-x

Rahimi Eichi V, Okamato M, Haefele SM, Jewell N, Brien C, Garnett T, Langridge P (2019) Understanding the interactions between biomass, grain production and grain protein content in high and low protein wheat genotypes under controlled environments. Agronomy 9. https://doi.org/10.3390/agronomy9110706

Rayment GE, Lyons DJ (2011) Soil chemical methods. CSIRO Publishing, Melbourne, Australia

Rebetzke GJ, Chapman SC, McIntyre CL, Richards RA, Condon AG, Watt M, van Herwaarden AF (2009) Grain yield improvement in water-limited environments. In: Wheat science and trade. John Wiley \& Sons, Ltd, pp 215-249

Reuter DJ, Robinson JB (1997) Plant analysis: an interpretation manual, 2nd edn. CSIRO Publishing, Melbourne, Australia

Riley RC, Cavagnaro TR, Brien C, Smith FA, Smith SE, Berger B, Garnett T, Stonor R, Schilling RK, Chen Z-H, Powell JR (2019) Resource allocation to growth or luxury consumption drives mycorrhizal responses. Ecol Lett 22:1757-1766. https://doi.org/10.1111/ele.13353

Schwinning S, Sala OE (2004) Hierarchy of responses to resource pulses in arid and semi-arid ecosystems. Oecologia 141:211-220. https:// doi.org/10.1007/s00442-004-1520-8

Semananda NPK, Ward JD, Myers BR (2016) Evaluating the efficiency of wicking bed irrigation systems for small-scale urban agriculture. Horticulturae 2. https://doi.org/10.3390/horticulturae2040013

Sitlington Hansen NJ (2019) Quantifying nitrogen use efficiency in wheat using high-precision phenotyping. University of Adelaide

Takahashi F, Tilbrook J, Trittermann C, Berger B, Roy SJ, Seki M, Shinozaki K, Tester M (2015) Comparison of leaf sheath transcriptome profiles with physiological traits of bread wheat cultivars under salinity stress. PLoS One 10:e0133322. https://doi.org/10. 1371/journal.pone.0133322

Tinklin R, Weatherley PE (1968) The effect of transpiration rate on the leaf water potential of sand and soil rooted plants. New Phytol 67: 605-615. https://doi.org/10.1111/j.1469-8137.1968.tb05487.x

Tran BTT, Cavagnaro TR, Jewell N, Brien C, Berger B, Watts-Williams SJ (2020) High-throughput phenotyping reveals growth of Medicago truncatula is positively affected by arbuscular mycorrhizal fungi even at high soil phosphorus availability. Plants, People, Planet 00:1-14. https://doi.org/10.1002/ppp3.10101

Wang L, Ruan Y-L (2016) Shoot-root carbon allocation, sugar signalling and their coupling with nitrogen uptake and assimilation. Funct Plant Biol 43:105-113. https://doi.org/10.1071/FP15249

Wang X, Shi Y, Guo Z, Zhang Y, Yu Z (2015) Water use and soil nitrate nitrogen changes under supplemental irrigation with nitrogen application rate in wheat field. F Crop Res 183:117-125. https://doi.org/ 10.1016/j.fcr.2015.07.021

Withington JM, Reich PB, Oleksyn J, Eissenstat DM (2006) Comparisons of structure and life span in roots and leaves among temperate trees. Ecol Monogr 76:381-397. https://doi.org/10.1890/ 0012-9615(2006)076[0381:COSALS]2.0.CO;2

Zhang H, Jennings A, Barlow PW, Forde BG (1999) Dual pathways for regulation of root branching by nitrate. Proc Natl Acad Sci U S A 96: 6529-6534. https://doi.org/10.1073/pnas.96.11.6529

Zheng Z-L (2009) Carbon and nitrogen nutrient balance signaling in plants. Plant Signal Behav 4:584-591. https://doi.org/10.4161/psb. 4.7.8540

Publisher's note Springer Nature remains neutral with regard to jurisdictional claims in published maps and institutional affiliations. 